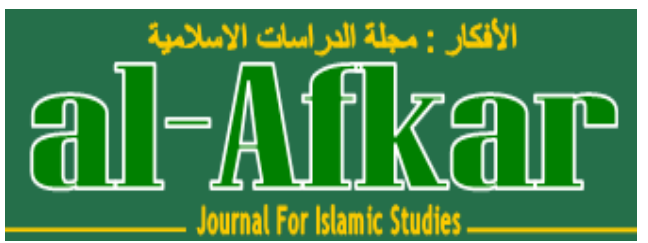

Vol. 2, No. 2, July 2019

P-ISSN : 2614-4883; E-ISSN : 2614-4905

https://al-afkar.com/index.php/Afkar_Journal/issue/view/4

DOI: https://doi.org/10.31943/afkar_journal.v4i1.61

\title{
KONSEPSI MARTABAT TUJUH DALAM WIRID HIDAYAT JATI RANGGAWARSITA
}

\section{Asep Lukman Hamid}

Universitas Islam Negeri Sunan Gunung Djati Bandung

E-Mail: amangasep99@gmail.com

\begin{tabular}{|c|c|c|}
\hline Received & Revised & Accepted \\
\hline 3 Juny 2019 & 20 Juny 2019 & 1 July 2019 \\
\hline
\end{tabular}

\section{THE CONCEPTION OF MARTABAT TUJUH IN WIRID HIDAYAT JATI OF RANGGAWARSITA}

\begin{abstract}
:
This research aims to answer: What is the background of writing the Wirid Hidayat Jati Book? , what is the concept of seven dignity in the book? , and how does it affect the spiritual behavior of the Javanese people? . By applying the library research and descriptive analysis can be concluded that: Ranggawarsita is a poet palace and is regarded as the coping stone of Javanese writers who are able to combine the teachings of Islam with Javanese mystical. Dignity seven is an understanding that God emanation as many as seven stages, namely sajaratul yakin, nur Muhammad, mirátul hayaí, roh idlafi, kandil, dharrah and hijab. Wirid Hidayat Jati is a mystical philosophy built by Ranggawarsita in response to the political and cultural situation of the Javanese people who have a strong tendency towards metaphysics such as ngelmu kasampurnan, ngelmu sangkan paran and manekung (semedi, tirakat).
\end{abstract}

Keywords: Martabat Tujuh, Wirid Hidayat Jati, Ranggawarsita. 


\begin{abstract}
Abstrak
Penelitian ini bertujuan untuk menjawab beberapa pertanyaan penelitian (research questions) yaitu: bagaimana latar belakang penulisan Kitab Wirid Hidayat Jati?, bagaimana konsep martabat tujuh dalam kitab tersebut?, dan bagaimana pengaruhnya terhadap laku spiritual masyarakat Jawa?. Dengan mengaplikasikan pendekatan kajian pustaka (library research) mengingat masalah yang diteliti adalah segala sesuatu yang berkenaan dengan isi Kitab Wirid Hidayat Jati. Adapun metode penelitiannya adalah analisis deskriptif sebab menganalisa data dengan penelaahan yang dilakukan secara intensif, mendalam, mendetail, dan komprehensif. Melalui pendekatan dan metode tersebut dapat disimpulkan bahwa: Pertama, Ranggawarsita adalah seorang pujangga Keraton dan dianggap sebagai pujangga penutup (as the coping stone of javanese writers) yang mampu menggabungkan antara ajaran tasawuf Islam dengan mistik Jawa. Kedua, martabat tujuh adalah sebuah pemahaman bahwa Tuhan ber-tajalli (baca: emanasi) sebanyak tujuh tahap, yakni sajaratul yakin, nur Muhammad, mirátul hayaí, roh idlafi, kandil, dharrah dan hijab. Ketiga, Wirid Hidayat Jati merupakan filsafat mistik yang dibangun oleh Ranggawarsita sebagai jawaban terhadap situasi politik dan budaya masyarakat Jawa yang memiliki kecenderungan kuat kepada alam metafisika seperti ngelmu kasampurnan, ngelmu sangkan paran dan manekung (semedi, tirakat).
\end{abstract}

Kata kunci: Martabat Tujuh, Wirid Hidayat Jati, Ranggawarsita.

\title{
Pendahuluan
}

Kepustakaan Islam Kejawen adalah salah satu kepustakaan Jawa yang memuat perpaduan antara tradisi Jawa dengan unsur-unsur ajaran agama Islam. Kepustakaan ini menggunakan tulisan (huruf) dan bahasa Jawa, sedangkan isinya cenderung bernuansa mistik dan sedikit yang mengungkapkan permasalahan syariat Islam. ${ }^{1} \quad$ Kepustakaan Islam Kejawen memiliki peran penting dalam sejarah penyebaran agama Islam di tanah Jawa dan masuk kategori kepustakaan Islam. Meskipun sebagian kepustakaan Islam Kejawen kurang memperhatikan aspek syariat (yang berkaitan dengan hukum Islam dan fikih), akan tetapi banyak juga yang menjadi sumber ajaran hidup bagi masyarakat Islam di Jawa. ${ }^{2}$ Hal yang sama juga diungkapkan oleh Hilman Hadikusuma, bahwa sebagian masyarakat Jawa yang merasa memiliki budaya "adiluhung" dan mencoba melestarikan budaya tersebut, menganggap bahwa ajaran-ajaran para leluhur yang tertuang dalam naskah-naskah klasik sebagai "buku suci". Hal ini dapat dilihat dari pakem (pedoman) ajaran Islam Kejawen dan munculnya aliran-aliran kebatinan yang muncul pada era sesudahnya

\footnotetext{
${ }^{1}$ Mistik Islam Kejawen Raden Ngabehi Simuh, "Ranggawarsita: Suatu Studi Terhadap Serat Wirid Hidayat Jati," Yogyakarta: IAIN Sunan Kalijaga, 1983.

${ }^{2}$ Samidi Khalim, “Salat Islam Kejawen," Semarang: Prima Media, 2010.
} 
banyak yang bersumber dari "buku-buku" (naskah klasik) karya sastra para pujangga keraton atau kalangan masyarakat penganutnya. ${ }^{3}$

Kepustakaan Islam Kejawen pada umumnya banyak mengajarkan tentang mistik dan budi pekerti luhur. Sebagaimana dijelaskan oleh Simuh, bahwa Wirid, Serat, dan Suluk memuat ajaran-ajaran tentang mistik Islam (tasawuf), sedangkan primbon berisi ramalan, doa, mantra, berbagai tradisi-ritual orang Jawa, dan sebagian kecil ajaran tentang syariat Islam. ${ }^{4}$

Sumber ajaran Islam Kejawen pada umumnya berasal dari karya sastra pujangga Jawa (pujangga kraton khususnya), yang memiliki nilai-nilai budi luhur dan dikeramatkan seperti serat suluk, wirid, primbon, disamping gubahan kisahkisah yang berasal dari pesantren baik yang berasal dari bahasa Arab maupun Melayu. ${ }^{5}$ Meskipun demikian, orang Kejawen tetap mempercayai al-Quran sebagai sumber utama dari segala pengetahuan yang ada. Dalam praktek keagamaannya orang-orang Islam Kejawen lebih banyak dipengaruhi oleh keyakinan, konsepkonsep, pandangan-pandangan, nilai-nilai budaya, dan norma-norma yang berada dalam alam pikirannya. ${ }^{6}$

Ajaran mistik yang menonjol dalam kepustakaan Islam Kejawen adalah konsep tentang martabat tujuh yang terdapat dalam buku Wirid Hidayat Jati karya Raden Ngabehi Ranggawarsita (untuk selanjutnya disebut Ranggawarsita). Sebagai filsafat mistik, Wirid Hidayat Jati merupakan kitab yang ringkas, padat dan lengkap. Dimulai dari keterangan tentang Tuhan, teori penciptaan secara emanasi, perincian tentang hakikat manusia, dan laku untuk mencapai penghayatan kesatuan kembali dengan Tuhan (Manunggaling Kawula-Gusti). Bahkan tercermin pula secara ringkas ajaran budi luhur sebagai sarana mendekati Tuhan.

Martabat tujuh dalam Wirid Hidayat Jati dijelaskan dalam Bab V, yakni tentang penghayatan gaib sebanyak tujuh martabat beserta godaan-godaan yang dapat menyesatkan. Konsep martabat tujuh ini berkaitan dengan teori penciptaan manusia sebagaimana dinyatakan berikut ini:

"mula-mula Aku menciptakan hayyu bermakna sajaratul yakin, yang tumbuh di alam adam makdum yang azali abadi. Lalu cahaya bernama Nur Muhammad. Lalu kaca bernama miratul hayaí. Lalu nyawa bernama ruh idlafi. Lalu lampu bernama Kandil. Lalu permata bernama darrah. Lalu dinding jalal bernama hijab, itulah yang merupakan penutup hadirat-Ku."7

\footnotetext{
${ }^{3}$ Hilman Hadikusuma, Antropologi Agama: Pendekatan Budaya Terhadap Aliran Kepercayaan, Agama Hindu, Budha, Kong Hu Cu, Di Indonesia. Bagian I., vol. 1 (Citra Aditya Bakti, 1993).

${ }^{4}$ Simuh, "Ranggawarsita: Suatu Studi Terhadap Serat Wirid Hidayat Jati."

${ }^{5}$ Simuh, Sufisme Jawa: Transformasi Tasawuf Islam Ke Mistik Jawa (Yayasan Bentang Budaya, 1995).

${ }^{6}$ Kebudayaan Jawa Koentjaraningrat and P N Baiai Pustaka, “Jakarta, 1984._," Pengantar Antropologi, Aksara Baru, Jakarta, 1974.

${ }^{7}$ Simuh, Sufisme Jawa, 217. bandingkan. Serat Wirid Hidayat Jati. tiknan.blogspot.co.id. diakses pada tanggal 03/12/2017.
} 
Pada sisi lain, dapat dikatakan bahwa bibit awal martabat tujuh merupakan pengembangan dari suatu paham ketuhanan dalam tasawuf yang cenderung ke arah pantheistis-monis. Suatu paham yang mengatakan bahwa segala sesuatu yang ada di alam semesta ini merupakan aspek lahir dari satu hakikat yang tunggal yakni Tuhan. Pemahaman ini berasal dari Ibnu Arabi, yang memperkenalkan emanasi wujud Allah, melalui filsafat Neo-Platonisme. Paham Wahdatul Wujud ini kemudian diikuti dan dikembangkan oleh Abdul Karim al-Jilli dengan kitabnya Al-Insan alKamil fi Marifat al-Awakhir wa al-Awail. Dari Gujarat (India Selatan) muncul pula Muhammad Fadlullah Burhanpuri yang menyusun risalah kecil berjudul Al-Tuhfah al-Mursalah ila Ruh al-Nabi, yang inti pahamnya disebut martabat tujuh. ${ }^{8}$

Berdasarkan alur pikir sebagaimana tersebut diatas, penulis terpanggil untuk melakukan kajian terhadap Kitab Wirid Hidayat Jati yang didalamnya membahas martabat tujuh. Berdasarkan dugaan sementara, bahwa martabat tujuh Ranggawarsita memiliki karakteristik yang khas sebagai hasil dari sinkretis (perbauran) dengan kepercayaan masyarakat Jawa pra-Islam. perlu diketahui bahwa Ranggawarsita sebagaimana dinyatakan oleh Alwi Shihab adalah profil bapak Kebatinan atau Kejawen. Karya-karyanya dianggap sebagai rujukan untuk kebatinan Jawa. ${ }^{9}$ Adapun masalah pokok dalam penelitian ini yaitu bagaimana latar belakang penulisan Kitab Wirid Hidayat Jati, bagaimana konsep martabat tujuh dalam kitab tersebut, dan bagaimana pengaruhnya terhadap laku spiritual masyarakat kejawen.

\section{Metode Penelitian}

\section{Obyek Penelitian}

Obyek utama dalam penelitian ini adalah Konsep atau ajaran Martabat Tujuh dalam Wirid Hidayat Jati Ranggawarsita. Buku ini merupakan hasil pemikiran Ranggawarsita yang ditulis pada abad ke-19. Dalam melakukan penelitian ini, penulis mengalami kesulitan dalam menemukan buku aslinya, setelah searching akhirnya mendapatkan buku tersebut, permasalahan lain muncul karena buku tersebut ditulis dengan menggunakan aksara jawa, tentu ini diluar kemampuan penulis. Untuk mengeliminasi kekurangan atau kelemahan, dalam penelitian ini penulis merujuk pada pendapatnya Simuh pakar Kejawen, mantan Rektor IAIN Sunan Kalijaga bahwa dalam memahami pemikiran Ranggawarsita tentang Martabat Tujuh dalam Wirid Hidayat Jati terdapat enam buah buku yang bervarian meliputi:

1. Buku yang diterbitkan oleh Administrasi Jawi Kandha, Surakarta 19o8. Buku ini diberi judul Serat Wirid;

2. Buku yang diterbitkan oleh Honggopradoto, Surakarta 1941. Buku ini terdiri dari dua bagian, yaitu Hidayat Jati dan Maklumat Jati;

\footnotetext{
${ }^{8}$ Ahmad Qodri Abdillah Azizy et al., Pemikiran Islam Kontemporer Di Indonesia (Kerjasama STAIN Ternate, Direktorat Perguruan Tinggi Agama Islam, Depag RI ..., 2005).

${ }^{9}$ Alwi Shihab, Islam Sufistik (Bandung: Mizan, 2001), 161.
} 
3. Buku terbitan R. Tanaya, Surakarta 1954. Buku ini berjudul Wirid Hidayat Jati. Buku ini lebih ringkas dengan beberapa tambahan yang terdapat didalam buku Honggopradoto;

4. Buku yang diterbitkan oleh Tan Khoen Swie, Kediri 1959. Yang berjudul Serat Wirid Hidayat Jati secara utuh, terdapat banyak pengurangan dan penambahan;

5. Manuskrip yang dikeluarkan oleh P.W. Van den Broek yang berjudul Serat Makrifat. Manuskrip ini aslinya tersimpan di Leiden dengan Kode Or.6766;

6. Manuskrip yang tersimpan di Leiden dengan Kode Or.6518. manuskrip ini berjudul Hidayat Jati. Dan Manuskrip ini diterima oleh Simuh dalam bentuk Mikrofilm yang terdiri dari dua bagian, yaitu Hidayat Jati dan Maklumat Jati. $^{10}$

Dari penelusuran terhadap buku-buku tersebut, nampak bahwa ranggawarsita tidak memberi judul yang jelas terhadap karyanya, sehingga para penerbit memberinya judul yang sekiranya sesuai dengan isinya. Dan dalam penelitian ini menggunakan Konsep Martabat Tujuh dalam Wirid Hidayat Jati Ranggawarsita. Berbeda dengan umumnya buku-buku Kejawen yang mengajarkan berbagai ramalan (petung), doa, ajimat dan mantra-mantra, dalam buku Wirid Hiayat Jati didalamnya berisi tata cara mengajar ilmu makrifat dan persyaratan guru dan murid, ajaran delapan orang wali secara singkat, wirid, serat makrifat, tandatanda akan datangnya masa ajal dan tata cara manekung, dan penghayatan gaib sebanyak tujuh martabat beserta godaan-godaan yang dapat menyesatkan. ${ }^{11}$ Dari isi buku tersebut, maka yang menjadi concern penelitian ini adalah Konsep Martabat Tujuh perspektif Ranggawarsita. Konsepsi martabat tujuh ini menjadi rujukan para penganut Islam Kejawen hingga sekarang.

\section{Teknik Pengumpulan Data}

Penelitian ini merupakan kajian pustaka (library research). Data utama penelitian ini adalah Buku Wirid Hidayat Jati Ranggawarsita. Namun dikarenakan penulis tidak menemukan naskah aslinya ${ }^{12}$, akhirnya penulis menggunakan buku sekunder ${ }^{13}$ second opinion yaitu yang ditulis oleh pakar Kejawen, Simuh. Yaitu:

\footnotetext{
${ }^{10}$ Simuh, Sufisme Jawa $\cdots, 213-214$.

${ }^{11}$ Ibid. 214-215.

${ }^{12}$ Metode Racut and Dalam Tasawuf, “Metode Racut Dalam Tasawuf Jawa;,” no. December (2017): 126-32, https://doi.org/10.5281/zenodo.1255216.

${ }^{13}$ Dalam teknik pengumpulan data terdapat dua jenis data yang digunakan, yaitu sumber primer dan sumber sekunder. Sumber primer adalah sumber data yang langsung memberikan data kepada pengumpul data, dan sumber sekunder merupakan sumber yang tidak langsung memberikan data kepada pengumpul data, misalnya lewat orang lain atau lewat dokumen. Sugiyono, Metode Penelitian Pendidikan: Pendekatan Kuantitatif, Kualitatif, dan R\&D, (Bandung: Penerbit Alfabeta, 2013), 193.
} 
1. Mistik Islam Kejawen Raden Ngabehi Ranggawarsita: Suatu Studi terhadap Serat Wirid Hidayat Jati, Jakarta: UI Press, 1998;

2. Äspek Mistik Islam Kejawen dalam Wirid Hidayat Jati”, dalam: Ahmad Rifaí Hasan (Ed.) Warisan Intelektual Islam Indonesia, Bandung: Mizan, 1990;

3. Tasawuf dan Perkembangannya dalam Islam, Jakarta: PT. Raja Grafindo, 1996;

4. Sufisme Jawa: Transformasi Tasawuf Islam ke Mistik Jawa, Yogyakarta: Bentang Budaya, 1996.

Kajian pustaka sama seperti penelitian pada umumnya, tidak didasarkan pada kepentingan pribadi, seperti ikatan tertentu dengan lokasi, keterbatasan atau ketersediaan dana. Namun dalam penelitian pustaka ini tidak harus menggunakan wawancara, observasi, daftar pertanyaan, FGD, dan sebagainya, termasuk analisis biografi atau otobiografi. ${ }^{14}$

\section{Analisis Data}

Tidak ada suatu penelitian ilmiah yang tidak melibatkan kajian kepustakaan oleh penelitinya. Pun dalam penelitian ini, peneliti mengaplikasikan pendekatan kajian pustaka (library research). ${ }^{15}$ Pendekatan ini dilakukan mengingat masalah yang akan diteliti adalah segala sesuatu yang berkenaan dengan isi buku Wirid Hidayat Jati. Adapun metode penelitiannya adalah analisis deskriptif ${ }^{16}$ sebab menganalisa data dengan penelaahan yang dilakukan secara intensif, mendalam, mendetail, dan komprehensif. Dalam metode ini, peneliti mengumpulkan data yang setepat-tepatnya dan selengkap-lengkapnya agar hasil penelitiannya obyektif dan sesuai dengan apa yang diinginkan oleh obyek yang diteliti. Penelitian literatur (library research) terhadap Buku Wirid Hidayat Jati ini dilakukan secara deskriptif analitis. Langkah pertama adalah melakukan klasifikasi isi pemikiran yang ada di dalam buku tersebut, kemudian menganalisis konsepsi martabat tujuh yang ada di dalamnya. Analisis ini dilakukan dengan pendekatan tasawuf ${ }^{17}$ dan hermeneutika, untuk mengungkapkan bagaimana konsepsi martabat tujuh yang ada dalam Wirid

\footnotetext{
${ }^{14}$ J Moleong, “Lexy. 2014, Metodologi Penelitian Kualitatif, Bandung: PT," Remaja Rosdakarya, n.d.

${ }^{15}$ Library research adalah penelitian yang datanya diambil terutama atau seluruhnya dari kepustakaan baik berupa buka, dokumen, artikel, laporan, Koran dan lain sebaginya. Lihat, Prasetya Irawan, Logika dan Prosedur Penelitian: Pengantar Teori dan Panduan Praktis Penelitian Sosial bagi Mahasiswa dan Peneliti Pemula (Jakarta: STIA-LAN Press, 2000), 65.

${ }^{16}$ Metodologi adalah pengetahuan tentang cara-cara (science of methods). Sedangkan metodologi penelitian mengandung makna "totalitas cara" untuk meneliti dan menemukan kebenaran. Disebut totalitas cara, sebab metodologi tidak hanya mengacu kepada metodologi penelitian, tetapi juga paradigm, pola pikir, metode pengumpulan dan analisis data, sampai kepada metode pnafsiran temuan penelitian itu sendiri. Ibid., 54

${ }^{17}$ Simuh, Sufisme Jawa: Transformasi Tasawuf Islam Ke Mistik Jawa.
} 
Hidayat Jati. Pendekatan dalam hal ini bukan teori, metode, atau teknik, tetapi dalam pendekatan terkandung teori, metode, teknik, instrument dan sebagainya. ${ }^{18}$

Pendekatan tasawuf ini merupakan sudut pandang yang penulis anggap paling relevan sesuai dengan tujuan penelitian. Adapun metode untuk memahami martabat tujuh tersebut adalah: berusaha menelaah buku Wirid Hidayat Jati sebagai satu kesatuan ajaran yang utuh; memahami dan menganalisis pokok-pokok ajaran tentang Konsepsi penciptaan alam semesta yang terkandung di dalamnya; dan berusaha untuk memahami konsep-konsep tasawuf dalam pemahaman dan kerangka pikir Islam Kejawen. Wirid Hidayat jati sebagai sebuah karya sastra dapat dianalisis secara langsung, sebab karya itulah yang dianggap sebagai sumber kepustakaan Islam Kejawen.

\section{Pembahasan dan Hasil}

\section{Ranggawarsita}

Ranggawarsita adalah keturunan pujangga, dia adalah cucu Yasadipura II, cucu buyut Yasadipura I. Yasadipura I, Yasadipura II dan Ranggawarsita adalah tiga orang pujangga Istana Surakarta. Ketiga pujangga istana inilah yang memainkan peranan utama dalam masa kebangkitan rohani dan pembaharuan kepustakaan Jawa. Ia dilahirkan pada tahun 1802 M dan wafat tahun 1873 M. ia dimakamkan di Desa Palar, Kecamatan Trucuk, Kabupaten Klaten. ${ }^{19}$

Suatu hal yang amat menarik bahwa Ranggawarsita disamping dibesarkan dan dididik dalam lingkungan pujangga dan Kesusastraan Jawa, ia juga seperti halnya kebanyakan para priyayi Jawa dikirim secara khusus ke Pesantren Tegalsari, di Ponorogo. Pada saat itu Pesantren Tegalsari diasuh oleh seorang guru agama yang populer, yaitu Kiai Ageng Kasan Besari. Di samping guru agama, ia juga merupakan ahli kebatinan yang masih berdarah priyai. Maka tidak heran jika Pesantren ini selain menghasilkan agamawan atau ulama, juga menghasilkan tokoh-tokoh priyayi dan negarawan.

Sebagai anak seorang pujangga, saat ia berada di Pesantren Tegalsari ternyata kurang rajin dalam mengkaji ilmu agama dan bahasa Arab. Hal ini menurut Simuh tampak dalam mengungkapkan unsur-unsur keislaman dalam karya-karyanya. Namun demikian suasana kehidupan Pesantren nampak berpengaruh besar bagi kepribadian dan wawasan pemikirannya. ${ }^{20}$ Diriwayatkan bahwa sebagai seorang putra priyayi di pesantren tegalsari ini ia mengalami tekanan batin. Tekanan batin ini menimbulkan kesadaran untuk meninggalkan cara kemudaannya yang penuh kenakalan, dan kemudian mesu budi dalam upaya peningkatan kemampuan rohaninya.

\footnotetext{
${ }^{18}$ Nyoman Kutha Ratna, Metodologi Penelitian, Kajian Budaya dan Ilmu Sosial Humaniora Pada Umumnya (Yogyakarta: Pustaka Pelajar, 2010), 45.

${ }^{19}$ M. Solihin, Sejarah dan Pemikiran Tasawuf di Indonesia (Bandung: Pustaka Setia, 2001), 97.

${ }^{20}$ Simuh, Sufisme Jawa, 182-183.
} 
Setelah kakeknya Yasadipura II meninggal, ia diangkat sebagai pujangga istana. Pengangkatan ini menunjukkan bahwa Ranggawarsita adalah tokoh yang telah menguasai ilmu kejawen. Karena kedudukan pujangga pada waktu itu berarti orang yang telah mahir dalam kesusastraan serta telah mumpuni dalam ilmu kejawen. Kedudukannya sebagai pujangga istana ia bertugas menyusun dan mengembangkan kebudayaan dan kesusastraan Jawa. Kalau kakeknya berjasa dalam menggubah kitab-kitab yang berbahasa kuno ke dalam bahasa Jawa baru, dan menyesuaikan dengan ajaran Islam, maka Ranggawarsita berhasil menyusun karyakarya baru yang dalam karyanya tersebut ia berusaha mempertemukan tradisi ilmu kejawen dengan unsur-unsur Islam. Diantara karyanya adalah Suluk Jiwa, ${ }^{21}$ Serat Pamoring Kawula Gusti, ${ }^{22}$ Suluk Sukma Lelana, ${ }^{23}$ Serat Paramayoga, ${ }^{24}$ dan Serat Wirid Hidayat jati. ${ }^{25}$

Dari karya-karyanya tersebut nampak bahwa pemikiran Ranggawarsita dipengaruhi oleh tasawuf Islam, terutama tasawuf al-Ghazali yang memadukan antara tarekat, hakikat dan makrifat. Pengaruh pemikiran al-Ghazali ini sangatlah besar, sehingga menurut Harun Hadiwiyono bahwa untuk mengetahui isi kitab Wirid Hidayat Jati maka orang tersebut harus memahami dulu ilmu kebatinan (baca: tasawuf) Islam. Sebagaimana dinyatakan berikut ini.

"Serat Wirid bukan buku yang mudah untuk dibaca, orang ingin mengetahui isinya secara mendalam harus terlebih dahulu mengetahui ajaran kebatinan Islam secara umum, umpamanya ajaran martabat tujuh dan sebagainya. ${ }^{26}$

Pada zaman Ranggawarsita, masa kebesaran karya sastra Jawa abad pembaharuan dan kebangkitan rohani zaman Surakarta. Masa ini boleh dikatakan sebagi kulminasi aspek spiritual dari sastra dan budaya Jawa. Yakni kulminasi kebesaran sastra yang bersifat mistik dan mitologis. Keduanya tidak dapat dipisahkan karena merupakan perpaduan antara kehalusan rasa dan penghayatan aspek spiritual keagamaan tradisi lama. Bahkan dalam pandangan Simuh, mistik, mitologis dan ditambah dengan feodal merupakan karakteristik sastra saat itu.

\footnotetext{
${ }^{21}$ Cerita simbolik yang meriwayatkan bahwa Wisnu menyerupakan diri sebagai seorang tokoh yang bernama Sulaiman yang berangkat ke Turki untuk mempelajari tasawuf di bawah bimbingan Syekh Usman An-Naji. Cerita simbolik ini kemudian berbicara tentang penciptaan.

${ }^{22}$ Gusti berbicara mengenai dzikir, dan larut dalam kontemplasi dan perenungan kepada Allah SWT. Dengan hati penuh rindu. Di tempat lain, dia juga berbicara tentang derajat manusia yang di bagi dalam golongan awam dan khawas, dan juga berbicara tentang tujuh martabat manusia, yaitu jasad, akal, jiwa, ruh, sirr, nur dan urip (kehidupan.).

${ }^{23}$ Sebuah risalah tasawuf yang memotivasi untuk membentuk budi pekerti luhur. Terdapat pula uraian pengorbanan Ali Zainal Abidin bin Husain. Dalam risalah ini juga Ranggawarsita berbicara tentang keutamaan latihan spiritual dan pembersihan jiwa.

${ }^{24}$ Sebuah risalah historis yang berupaya menyesuaikan antara legenda Tuhan dalam Hinduisme dengan para Nabi dalam Islam. Risalah ini juga berbicara tentang martabat wujud. Dan akhirnya risalah ini diakhiri dengan paham jabariyyah.

${ }^{25}$ M. Solihin, Sejarah dan Pemikiran Tasawuf, 97.

${ }^{26}$ Harun Hadiwiyono, Kebatinan Jawa Abad ke-19, (Yogyakarta:, t.t)., v.
} 
Karena kebesarannya itulah, Ranggawarsita sering disebut sebagai pujangga penutup (as the coping stone of javanese writers). ${ }^{27}$

\section{Martabat Tujuh}

Kitab Wirid Hidayat Jati mengajarkan bahwa Dzat Tuhan memiliki berbagai macam sifat, asma dan afál. Tuhan digambarkan sebagai Dzat yang berkehendak dan berkarya secara aktif, sebagai pencipta dan penguasa alam semesta. Dengan adanya sifat, asma dan afál ini berarti Wirid Hidayat Jati mengajarkan paham Ketuhanan yang bersifat Theis.

Sebagai suatu bentuk ajaran Ketuhanan, maka uraian dalam wirid Hidayat Jati tak dapat dipisahkan dari uraiannya tentang manusia. ${ }^{28}$ Mengenai penciptaan manusia, dalam Wirid Hidayat Jati melalui tajalli Dzat-Nya sebanyak tujuh martabat, yakni sajaratul yakin, nur Muhammad, mirátul hayaí, roh idlafi, kandil, dharrah dan hijab. Berdasarkan keterangan tersebut maka dapat diuraikan sebagai berikut:

1. Tajally pertama, sajaratul yakin. Yaitu tajalli pertama daripada Dzat Tuhan, masih berupa Dzat mutlak yang tunggal. Ia juga disebut hayyu (hidup) atau atma, tidak dapat diketahui bagaimana keadaannya, tidak dapat diserupakan dengan apapun. Sajaratul yakin, tumbuh dalam alam-makhdum yang sunyi senyap azali abadi, artinya pohon kehidupan yang berada dalam ruang hampa yang sunyi senyap selamanya, belum ada sesutupun, adalah hakikat Dzat mutlak yang Qadim. Yakni hakikat Dzat yang pasti terdahulu, yaitu dzat atma, yang menjadi wahana alam Ahadiyat.

2. Martabat kedua yaitu Nur Muhammad yakni cahaya yang terpuji. Diceritakan dalam hadits, rupanya seperti burung merak, berada didalam permata putih, ada pada arah sajaratul yakin. Itulah hakikat cahaya yang diakui sebagai tajalli al-Dzat, berada dalam nukat ghaib merupakan sifat atma menjadi wahana alam wahdat.

3. Martabat ketiga adalah mirátul hayaí. Dalam Wirid Hidayat Jati diuraikan bahwa mirátul hayaí artinya kaca wiraí. Diceritakan dalam hadits, berada di depan Nur Muhammad itulah hakikat pramana, yang diakui rahsa Dzat sebagai asma atma, menjadi wahana alam Wahidiyat.

4. Martabat keempat dinamakan ruh idlafi. Ruh idlafi ini diartikan sebagai nyawa yang jernih. Diceritakan dalam hadits berasal dari Nur Muhammad. Itulah hakikat sukma yang diakui keadaan Dzat, merupakan afál atma, menjadi wahana alam arwah.

5. Martabat kelima dinamakan kandil, yakni lampu tanpa api. Diceritakan dalam hadits berupa permata yang bercahaya berkilauan, tergantung tanpa kaitan. Itulah keadaan Nur Muhammad, tempat berkumpul semua roh. Adalah

\footnotetext{
${ }^{27}$ Simuh, Sufisme Jawa $\cdots 151$.

${ }^{28}$ M. Solihin, Sejarah dan Pemikiran Tasawuf, 98.
} 
hakikat angan-angan yang diakui sebagai bayangan Dzat, menjadi bingkai atma, dan menjadi wahana álam mitsal.

6. Martabat keenam ialah dzarrah yang berarti permata. Tersebut dalam hadita punya sinar beraneka warna, kesemuanya ditempati malaikat. Itulah hakikat budi, yang diakui sebagai perhiasan Dzat, merupakan pintu atma, dan menjadi wahana alam ajsam.

7. Martabat ketujuh atau yang terakhir adalah hijab, yaitu tabir yang agung. $H i j a b$ disebut dinding jalal, artinya tabir yang agung. Diceritakan dalam hadits, timbul dari permata yang beraneka warna, pada waktu gerak menimbulkan buih, asap dan air. Itulah hakikat jasad, merupakan tempat atma, menjadi wahana alam insan kamil. $^{29}$

Adapun versi asli martabat tujuh adalah apa yang di tulis oleh Muhammad Fadlullah Al-Burhanfuri dalam kitabnya al-Tuhfah al-Mursalah ila Ruh al-Naby, dan sebagai perbandingan berikut ini akan diuraikan versinya, yaitu:

$$
\begin{aligned}
& \text { ان دلك الوجودفي تلك المرتبة منزه عن اضافة النعوت والصفات ومقدس عن كل قيد, } \\
& \text { مرتبة التعين الاول وهى عبارة عن علمه تعالى لداته وصفاته ولجميع الموجودات على وجه الاجمال } \\
& \text { من غيرامتيازبعضهاعن بعض وهده تسمى بالوحدة والحقيقة المحمدية, مرتبة التعين الثانى وهي عبارة } \\
& \text { عن علمه تعالى لداته ولصفاته وبلميع الموجودات على طريقة التفصيل وامتيازبعضها عن بعض, } \\
& \text { فهده ثلاث مراتب كلهاقديمة والتقديم والتاخير عقلي لازماني, مرتبة عالم الارواح وهى عبارة عن } \\
& \text { الاشياءالكونية المحردة, مرتبة عالم المثال وهى عبارة عن الاشياء الكونية المركبة اللطيفة التى لا تقبل } \\
& \text { التجزى والتبعيض, مرتبة عالم الا جسام وهى عبارة عن الاشياء الكونية المركبة الكشفية التى تقبل } \\
& \text { التجزى والتبعيض, والمرتبة السابعة المرتبة الجمامعة لجامع المراتب المدكورة الجمسمنية والنورنية والوحدة } \\
& \text { والواحدية والهى التجلى الاخرواللباس الاخروهي الانسان }
\end{aligned}
$$

Menurut Fadlullah al-Burhanfuri, sebagaimana dikemukanakn diatas bahwa Tuhan sebagai Dzat mutlak yang qadim tidak dapat diketahui oleh pancaindera, akal ataupun khayal (waham). Tuhan sebagi wujud mutlak baru bisa dikenal setelah bertajalli (menampakkan keluar) sebanyak tujuh martabat yaitu:

1. Alam Ahadiyat, yaitu martabat Dzat yang bersifat la taáyun atau martabat sepi, Dzat yang bersifat mutlak, tiada dapat dikenal oleh siapapun;

\footnotetext{
${ }^{29}$ M. Wildan Yahya, Menyingkap Tabir Rahasia Spiritual, 126 - 129.
} 
2. Martabat Wahdah atau hakikat Muhammadiyyah (Nur Muhammad). Yaitu permulaan taáyun yang merupakan kesatuan yang mengandung kejamakan di mana belum ada pemisahan satu terhadap lainnya;

3. Martabat Wahidiyat atau hakikat manusia, yaitu kesatuan yang mengandung kejamakan, dimana setiap bagian telah nampak terpisah-pisah secara jelas. Ahadiyat, Wahdat dan Wahidiyah disebut martabat batin yang bersifat qadim dan tetap, dan muncullah empat martabat lahir dan merupakan áyan tsabitah, yaitu:

4. Martabat Alam Arwah, yaitu ibarat segala sesuatu yang masih mujarod dan basit;

5. Martabat alam mitsal, yaitu segala sesuatu yang tersusun secara halus, tidak dapat dibagi dan tak dapat dipisahkan satu dengan lainnya;

6. Martabat alam ajsam, ibarat segala sesuatu yang telah terukur. Telah jelas tebal tipisnya, dapat dibagi-bagi; dan

7. Martabat insan kamil, mencakup keenam martabat yang terdahulu yakni ahadiyat, wahdat, wahidiyat, alam arwah, alam mitsal dan alam ajsam.

Konsep martabat tujuh yang terdapat dalam Wirid Hidayat Jati memiliki hubungan dengan konsep martabat tujuh dalam Sekar Macapat, Serat Centini dan Naskah Pamijahan, yang secara ${ }^{30}$ substansial masih mengikuti pokok-pokok uraian yang tertuang di dalam kitab al-Tuhfah al-Mursalah ilah Ruh al-Naby, sekalipun terdapat pendekatan substansial yang sama, akan tetapi pada dataran praktis, khususnya pada Wirid Hidayat Jati terdapat banyak perkembangan kajian, setidaknya ada tiga hal yang membedakan Wirid Hidayat Jati dari yang lainnya, yaitu:

1. Martabat tujuh diartikan sebagai proses penciptaan manusia dan ke tujuh unsur manusia dibuat sejajar;

2. Wirid Hidayat Jati tidak membuat pembedaan antara áyan tsabitah dengan áyan kharijiah; dan

3. Wirid Hidayat Jati menggunakan istilah-istilah yang berbeda sekalipun melakukan kesepadanan.

Berdasarkan hasil kajian teks yang diambil dari kitab-kitab yang mewakili ritus dan kepercayaan sufistik Islam Jawa tersebut, dapat dikemukakan disini bahwa Islam memiliki warna yang sangat dominan dan ikut membentuk karakter interaksi sosial masyarakat Jawa. Sebagaimana dinyatakan oleh Mark Wood berikut ini:

"saya menghabiskan beberapa hari untuk menelusuri elemen-elemen Hindu dari ideologi dan modalitas ritual upacara yang saya amati tersebut, tetapi

\footnotetext{
${ }^{30}$ Sumadi Sumadi, "IDEOLOGI BIAS GENDER DALAM LEMBARAN FIKIH POPULER DI INDONESIA," Al-Afkar, Journal For Islamic Studies 1, no. 1 (2018): 1-15.
} 
semuanya nihil. Usaha saya untuk menemukan prototipe-prototipe Hindu dan Budha dari mistisisme Jawa tradisional juga sama mengecewakan. Tidak ada sistem teravada, Mahayana, Siva atau Vaisnaca yang saya pelajari yang tampak dikandungnya kecuali sekedar kesamaan, yang bagi para informan Jawa, sangat sepele. ${ }^{31}$

Pandangan Wood tersebut jelas menekankan dominasi warna Islam dalam kepercayaan dan tradisi sufistik Jawa, akan tetapi dari sudut etnologis, terutama Clifford Gertz, mengemukakan pandangan yang berlawanan. Ia mengatakan bahwa Islam tidak pernah sungguh-sungguh dipeluk di Jawa kecuali di kalangan komunitas kecil para pedagang, hampir tidak ada sama sekali di lingkungan Keraton. Karenanya ia membagi kelompok masyarakat Jawa ke dalam tiga varian, yaitu santri, yang merupakan kalangan muslim ortodoks; priyayi, kalangan bangsawan yang dipengaruhi terutama oleh tradisi-tradisi Hindu Jawa; dan Abangan, masyarakat desa pemeluk animisme. ${ }^{32}$

Pendapat Geertz tersebut ditentang oleh Hodgson yang menegaskan bahwa memang studi yang paling penting mengenai Islam di Indonesia adalah Religion of Java-nya Geertz, tetapi keunggulannya tersebut secara umum terganggu oleh kesalahan yang sangat sistemtis karena Geertz, terlalu terpengaruh oleh Islam Syariáh modern sehingga ia hanya mengidentifikasi Islam dengan mazhab modernis dan menganggap segala sesuatu sebagai asli atau berlatar belakang Hindu-Budha dan dengan serampangan ia menamakan banyak kehidupan keagamaan umat Islam di Jawa sebagai Hindu. ${ }^{33}$

Sementara itu Wood juga menyatakan pendapatanya bahwa konsep masuknya unsur-unsur simbolisme dan ikonografi Hindu dan Budha ke dalam Islam Jawa sama seperti Islam di Timur Tengah yang menyerap unsur-unsur tradisi Hellenistik dan Persia. Tidak ada tradisi keagamaan dan kebudayaan yang eksis secara terisolir. ${ }^{34}$

Dalam Wirid Hidayat Jati, Hayyu atau hidup mendapat penyerahan kekuasaan dari Dzat yang Maha Suci untuk menghidupi seluruh bagian dan anggota badan, termasuk juga ruh dihidupi oleh hayyu. Selain itu dijelaskan juga bahwa tujuan hidup manusia harus berusaha bersatu dengan Tuhan. Kesatuan dengan Tuhan ini bisa dicapai di dunia dengan jalan melakukan manekung ${ }^{35}$ dan dengan membaca ungkapan- kata-kata untuk mengumpulkan kawula-Gusti. Akan tetapi kesatuan kembali dengan Tuhan yang sempurna adalah sesudah mengalami masa

\footnotetext{
${ }^{31}$ Mark R. Wood, Islam in Java: Normatives Piety and Mysticism in The Sultanate of Yogyakarta (The Asia Foundation, 1989), 4.

${ }^{32}$ Clifford Geetz, Abangan, Santri Priyayi dalam Masyarakat Jawa (Jakarta: Pustaka Jaya, 1989)

${ }^{33}$ Marshall Hodgson, The Venture of Islam: Conscience and History in a World Civilization, Vol. III (Chicago: University of Chicago Press, 1974), 551.

${ }^{34}$ Mark R. Wood, Islam in Java, 4.

35 Manekung adalah mengkonsentrasikan seluruh pikiran dan kesadaran untuk merenungkan keagungan Tuhan dengan melalui membaca dzikir.
} 
ajal (mati). ${ }^{36}$ Istilah manekung dalam Wirid Hidayat Jati memiliki kesamaan dengan jalan tasawuf Islam yaitu via contemplative. Sebagaimana diketahui bahwa dalam tarekat terdiri dari dua bagian yakni mujahadah yang berupa renungan batin dan riyadhat (latihan ruhani). Untuk yang pertama dalam istilah mistik disebut dengan via purgative sedangkan yang kedua disebut dengan via contemplative. ${ }^{37}$

\section{Mistik Jawa}

Mistik adalah suatu kepercayaan bahwa manusia dapat mengadakan komunikasi langsung atau bahkan bersatu dengan Tuhan (Kasunyatan Agung) melalui tanggapan batin di dalam meditasi. ${ }^{38}$ Ajaran Mistik yang diusahakan dan disesuaikan dengan ajaran Islam disebut tasawuf. Tujuan utama bertasawuf adalah untuk menetapkan keyakinan agamanya dengan menyaksikan langsung Dzat Tuhan yang disebut dengan hakikat. Orang yang berhasil meraihnya disebut makrifat. Alat untuk melihat Tuhan bukanlah pancaindra atau akal, melainkan kalbu (mata hati, indra batin).

Dalam paradigma tasawuf, hati ini diibaratkan cermin, apabila cermin hatinya dapat dibersihkan dari segala kotoran atau ikatan keduniaan, dan diarahkan ke hadirat Tuhan dengan meditasi (dzikir) akan dapat menerima nur ghaib dari alam gaib dan dari Tuhan, sehingga Tuhan dapat terlihat dalam cermin hatinya. Itulah yang disebut dengan makrifat. ${ }^{39}$ Dengan penghayatan marifat, para sufi keyakinan agamanya semakin mantap. Yakni dapat mencapai tingkat haqul yakin, bukan hanya ainul yakin atau ilmu yakin saja. Jalan untuk mencapai penghayatan marifat disebut dengan tarekat. ${ }^{40}$

Diatas telah disebutkan bahwa jalan untuk sampai bersatu dengan Tuhan adalah melalui penyucian hati dari segala bentuk ikatan keduniaan yang dapat dicapai melalui tujuh maqam yaitu maqam taubat, wara, zuhud, fakir sabar, tawakal dan rela. Penyucian hati melalui tujuh maqam ini pada hakikatnya merupakan pembinaan ke arah budi luhur. Sesudah hatinya suci barulah dia melakukan meditasi dengan berdzikir. Maditasi atau dzikir pada hakikatnya berusaha mengalihkan kesadaran terhadap dunia luar untuk dipusatkan di alam batin, apabila ia berhasil maka ia akan melihat nur gaib di dalam hatinya. Inilah yang disebut

\footnotetext{
${ }^{36}$ Simuh, Sufisme Jawa, 218.

${ }^{37}$ Via Purgative adalah upaya yang ditempuh oleh seorang sufi melalui penyucian hati melalui tujuh maqam kenaikan ruhani yaitu: taubat, wara, zuhud, fakir, sabar, tawakal, dan ridha. Sedangkan via contemplative berupa amal-amal praktis (riyadhat) sebagai sarana pemusatan pikiran dan kesadaran hanya pada dzat Allah dengan penuh emosional (rindu dendam). Lihat, Simuh, Tasawuf dan Perkembangannya dalam Islam, (Jakarta: PT RajaGrafindo Persada, 1997), 208-209.

${ }^{38}$ A. S. Hornby dkk., A Learners Dictionary of Current English, 828.

${ }^{39}$ Marifat ialah Itiqad yang jazam lagi sesuai pada hak dengan dalil atau hujjah. Lihat. Barmawi Umari, Sistimatik Tasawwuf (Solo: RAMADHANI, 1993), 19.

${ }^{40}$ Tarikat adalah jalan atau sistem yang ditempuh menuju keridhaan Allah semata-mata. Adapun ikhtiar menempuh jalan itu dinamakan suluk, sedangkan orangnya dinamakan salik. Jadi tarekat adalah saluran dari tasawuf. Barmawi Umari, Sistimatik Tasawwuf, 116.
} 
pengalaman keagaamaan yang tinggi yaitu fana. Setelah orang berasil fana dalam perspektif Muhammad Fadlullah Burhanpuri dalam tuhfah, ialah yang disebut dengan insan kamil (orang sempurna, orang suci, wali kekasih Allah), dan dengan sendirinya mereka memiliki ilmu gaib, dapat jampi-jampi dan mantra-mantra bahkan dipandang sebagai wali yang sakti weruh sadurunge winarah, serta mempunyai berbagai macam kekeramatan.

Adapun puncak penghayatan marifat dalam tasawuf terdapat dua paham, yaitu yang mempertahankan konsep dualisme yang menarik garis perbedaan yang tegas antara Tuhan sebagai Dzat yang wajibul wujud dan bersifat transendent, menurutnya bahawa marifat yang tinggi hanyalah sampai ke hadirat Tuhan, manusia yang hidupnya diimbasi sifat-sifat ketuhanan. Dan segolongan lagi adalah para penganut tasawuf yang cenderung ke arah paham pantheisme dan monisme. Mereka memandang Tuhan bersifat Immanent atau bersemayam dalam diri manusia dalam mistik Jawa disebut dengan Manunggaling Kawula-Gusti. Menurut Simuh, bahwa dalam Wirid Hidayat jati nampak jelas dipengaruhi oleh paham pantheisme. ${ }^{41}$

Inti ajaran Wirid Hidayat Jati boleh dibilang merupakan perpaduan antara ajaran martabat tujuh dari mistik Islam dan penghayatan gaib dari Dewaruci. Dus, inti ajaran maupun konsep ajaran martabat tujuh cukup mewarnai alam pikiran mistik Ranggawarsita dalam Wirid Hidayat Jati dengan sentuhan perubahan yang unik karena memiliki ciri khas sendiri sebagai hasil dari sinkretis dengan kepercayaan setempat. $^{42}$

Mistik Islam Kejawen adalah mistik yang dipadu dengan tradisi kejawen. Karya ini memuat pokok-pokok ajaran Islam yang disesuaikan dengan alam pikiran kejawen. ${ }^{43}$ Hanya saja harus diakui bahwa Wirid Hidayat jati Ranggawarsita tampak lebih dominan unsur kebatinan Jawanya daripada unsur Islamnya.

Yang perlu dicatat disini adalah ciri dari seni budaya dan sastra Jawa (Kejawen) yang tumbuh subur saat itu. Yakni wataknya yang sangat mistis, mitologis dan feodalis. Agaknya, semua itu merupakan kompensasi dari akibat ditelanjanginya kekuasaan politik kenegaraan oleh kolonial Belanda serta ditambah dengan keinginan para priyayi sendiri untuk mencari kebesaran dan kewibawaan dalam alam yang serba mistis dan mitologis. Demi maksud tersebut maka karya sastra dan budayalah yang dapat menjadi wasilah yang paling efektif untuk mempertahankan kebesaran Raja dan hak-hak istimewa para priyayi.

Masyarkat atau sekelompok manusia yang terlembaga pasti memiliki pandangan tertentu terhadap kepercayaan agamanya, seperti halnya masyarakat Jawa. Kepercayaannya itu disebut dengan istilah Kejawen. Kejawen berasal dari kata "Jawa", yang berarti segala sesuatu yang berhubungan dengan adat dan kepercayaan Jawa (Kejawaan). Dalam praktiknya Kejawen adalah sebuah kepercayaan yang

\footnotetext{
${ }^{41}$ Simuh, Sufisme Jawa, 198.

${ }^{42}$ M. Solihin, Sejarah dan Pemikiran Tasawuf, 98-99.

${ }^{43}$ Simuh, Äspek Mistik Islam Kejawen dalam Wirid Hidayat Jati dalam Ahmad Rifaí Hasan (ed.) Warisan Intelektual Islam Indonesia (Bandung: Mizan, 1990), 63-65.
} 
terutama dianut di pulau Jawa oleh suku jawa dan suku bangsa lainnya yang menetap di Jawa. Kejawen pada hakikatnya adalah suatu filsafat dimana keberadaaaannya ada sejak orang Jawa itu ada.

Kepercayaan masyarakat Jawa berangkat dari suatu religi yang berupa konsep-konsep atau gagasan yang menyangkut tentang Tuhan, manusia dan alam semesta, atau berupa keyakinan yang bersifat kosmogoni (alam dunia) dan eskatologi (alam akhirat). Dalam praktiknya wujud masyarakat Jawa adalah toleran dan terbuka terhadap pengaruh dari luar Jawa, hal ini diungkapkan oleh Koentjaraningrat sebagai berikut:

"Sikap orang Jawa adalah toleran, terutama yang beragama Islam Jawa, untuk bersikap toleran terhadap pendirian-pendirian lain; tentunya selama pendirian lain itu tidak menganggu sendi-sendi kehidupan kita, maka pendirian lain itu kita biarkan hidup dan kita usahakan tidak memerangi atau membasminya." ${ }^{44}$

Sikap masyarakat Jawa yang toleran tersebut ketika dikaitkan dengan dakwah Islam terjadi proses dialogis dengan budaya lokal sehingga melahirkan kondisi keberagamaan yang sinkretis, dan pada gilirannya disebut sebagi Islam Abangan atau adat Kejawen. ${ }^{45}$ Ajaran Mistik dan kepercayaan yang mitologi dan serba magis merupakan wujud sinkretisme keberagamaan masyarakat Jawa Islam. Kepercayaan ini sebagai sarana untuk mempertahankan kepercayaan Jawa terhadap konsep "raja titising Dewa" (God King). Oleh karena itu para pujangga yang bertugas demi maksud tersebut sangat aktif menyerap ajaran tokoh-tokoh sufi yang beraliran union-mistik (Manunggaling Kawula-Gusti) bagi pengembangan ajaran ilmu Kejawen. ${ }^{46}$ Oleh karena itu ajaran ketuhanan al-hallaj, Ibnu Árabi, Abdul Karim alJilli dan Hamzah Fansuri beserta para murid-muridnya seperti Nurudin ar-Raniri dan Syamsuddin Pase sangat digemari kalangan Kejawen.

\section{Simpulan}

Wirid Hidayat Jati merupakan kitab yang ringkas, padat dan lengkap. Dimulai dari keterangan tentang Tuhan, teori penciptaan secara emanasi, perincian tentang hakikat manusia, dan laku untuk mencapai penghayatan kesatuan kembali dengan Tuhan (Manunggaling Kawula-Gusti). Bahkan di dalamnya juga dibahas secara ringkas mengenai ajaran budi luhur sebagai sarana mendekati Tuhan.

Wirid Hidayat Jati merupakan filsafat mistik yang dibangun oleh Ranggawarsita sebagai jawaban terhadap situasi politik dan budaya masyarakat jawa yang memiliki kecenderungan kuat kepada alam metafisika seperti ngelmu

\footnotetext{
${ }^{44}$ Koentjaraningrat, Kebudayaan Mentalitas dan Pembangunan (Jakarta: PT Gramedia, 1984), 71.

${ }^{45}$ Sulkhan Chakim, "Potret Islam Sinkretisme: Praktik Ritual Kejawen” , dalam KOMUNIKA, Jurnal Dakwah dan Komunikasi, Vol. 3, No. 1, Januari-Juni 2009, 1.

${ }^{46}$ Simuh, Sufisme Jawa, 223.
} 
kasampurnan, ngelmu sangkan paran dan manekung (semedi, tirakat). Dengan mempelajari metafisika, diharapkan mampu menjadi insan kamil, manusia yang memiliki kekuatan magis (karamah). Setelah karamah itu didapat maka konsekuensinya bahwa segala petuahnya akan dipatuhi oleh masyarakatnya sebab dia adalah raja titisan Dewa.

\section{DAFTAR PUSTAKA}

Azizy, Ahmad Qodri Abdillah, Adnan Mahmud, Sahjad M Aksan, and M Adib Abdushomad. Pemikiran Islam Kontemporer Di Indonesia. Kerjasama STAIN Ternate, Direktorat Perguruan Tinggi Agama Islam, Depag RI ..., 2005.

Hadikusuma, Hilman. Antropologi Agama: Pendekatan Budaya Terhadap Aliran Kepercayaan, Agama Hindu, Budha, Kong Hu Cu, Di Indonesia. Bagian I. Vol. 1. Citra Aditya Bakti, 1993.

Khalim, Samidi. “Salat Islam Kejawen.” Semarang: Prima Media, 2010.

Koentjaraningrat, Kebudayaan Jawa, and P N Baiai Pustaka. "Jakarta, 1984.-." Pengantar Antropologi, Aksara Baru, Jakarta, 1974.

Moleong, J. “Lexy. 2014, Metodologi Penelitian Kualitatif, Bandung: PT.” Remaja Rosdakarya, n.d.

Racut, Metode, and Dalam Tasawuf. "Metode Racut Dalam Tasawuf Jawa;" no. December (2017): 126-32. https://doi.org/10.5281/zenodo.1255216.

Simuh. Sufisme Jawa: Transformasi Tasawuf Islam Ke Mistik Jawa. Yayasan Bentang Budaya, 1995.

Simuh, Mistik Islam Kejawen Raden Ngabehi. "Ranggawarsita: Suatu Studi Terhadap Serat Wirid Hidayat Jati.” Yogyakarta: IAIN Sunan Kalijaga, 1983.

Sumadi, Sumadi. "IDEOLOGI BIAS GENDER DALAM LEMBARAN FIKIH POPULER DI INDONESIA.” Al-Afkar, Journal For Islamic Studies 1, no. 1 (2018): 1-15.

Lukman, Asep. Martabat Alam Tujuh Dalam Perspektif Syekh Abdul Muhyi: Telaah Kritis atas Pemikiran Syekh Abdul Muhyi tentang Martabat Alam Tujuh, Bandung: LP2M UIN Sunan Gunung Djati Bandung, 2015.

Moleong, Lexy J. Metodologi Penelitian Kualitatif: Edisi Revisi, Bandung: PT Remaja Rosdakarya, 2013.

Ratna, I. Nyoman Kutha. Metodologi Penelitian, Kajian Budaya dan Ilmu Sosial Humaniora Pada Umumnya, Yogyakarta: Pustaka Pelajar, 2010.

Shihab, Alwi. Islam Sufistik, Bandung: Mizan, 2001.

Simuh, Mistik Islam Kejawen Raden Ngabehi Ranggawarsita, Jakarta: UI-Press, 1998.

Simuh, Sufisme Jawa: Transformasi Tasawuf Islam ke Mistik Jawa, Yogyakarta: Bentang Budaya, 1996. 
Simuh, Tasawuf dan Perkembangannya dalam Islam, Jakarta: PT RajaGrafindo Persada, 1997.

Solihin, M. Sejarah dan Pemikiran Tasawuf di Indonesia, Bandung: Pustaka Setia, 2001.

Sugiyono, Metode Penelitian Pendidikan: Pendekatan Kuantitatif, Kualitatif, dan RED, Bandung: Penerbit Alfabeta, 2013.

Yahya, M. Wildan. Menyingkap Tabir Rahasia Spiritual Syekh Abdul Muhyi: Menapaki Jejak Para Tokoh Sufi Nusantara Abad XVII \& XVIII, Bandung: Refika Aditama, 2007. 